\title{
Appraisal of Nigeria's Obligation on Adolescents' Access to Sexual and Reproductive Health Care
}

\author{
Oluremi A. Savage-Oyekunle (LLB, LLM, LLD) \\ Faculty of Law, Lagos State University, Lagos, Nigeria
}

Doi: 10.19044/esj.2018.v14n6p466 URL:http://dx.doi.org/10.19044/esj.2018.v14n6p466

Abstract

The positive obligations on states parties to ensure covenant rights will only be fully discharged if individuals are protected by the state, not just against violations of covenant rights by its agents, but also against acts committed by private persons or entities that would impair the enjoyment of covenant rights.... (Paragraph 8 General Comment 31 Human Rights Committee)

This article explores the responsibility of the Nigerian state towards ensuring female adolescents' access to sexual and reproductive health (SRH) care information and services especially contraceptive information and services. It thereafter, considers the stance of the treaty monitoring bodies to state parties' obligations on the right to access SRH care information and services. The article concludes by declaring the need for judicial activism and stricter monitoring of the government's activities in other to ensure that adolescents enjoy actual access to SRH care information and services.

Keywords: Adolescents, Sexual and Reproductive Health Rights (SRHR), State Party Obligations

\section{Introduction}

Until recently, adolescents (Cook, Dickens \& Fathalla, 2003, p. 276) were considered a relatively healthy group. They were considered relatively free of the heavy burden of disease that is part of the lives of adults and infants (Dehne \& Riedner, 2005). However, research has shown that, as they grow into adulthood and begin to engage in sexual relationships, adolescents increasingly become exposed to risks which predispose them to ill-health (Bankole \& Malarcher, 2010). In addition to becoming susceptible to contracting sexually-transmitted infections (STIs), including HIV, because 
sexual relations among adolescents are often unplanned, the majority of adolescent girls are at risk of unintended pregnancies (Shaw, 2009).

These risks to their SRH, coupled with the fact that adolescents represent a staggering 1.2 billion population world-wide (United Nations Population Fund (UNFPA), 2016; United Nations Children's Fund (UNICEF), 2011), the foundation of the world's future, underscore the urgent need to invest in young people's SRH, including their access to contraceptive information and services.

In developing countries where majority of adolescents reside; in subSahara Africa, where adolescent girls account for about one-sixth of all women of reproductive age (UNICEF, 2011, p.5) and in Nigeria, where adolescents' form $22 \%$ of the country's total population (UNICEF, 2013), the need to ensure access to SRH information and services for adolescents (especially female adolescents) is urgent. In sub-Saharan Africa, STIs and HIV - the leading causes of loss of health among women of reproductive age - predominantly affects adolescent girls (Mbizvo \& Zaidi, 2010; Glasier, 2006).

In addition to their susceptibility to STIs and HIV, is the problem of teenage pregnancy which, according to the UNFPA, is rampant as over 7.3 million girls under the age of 18 give birth annually in developing countries (UNFPA, 2011; UNFPA, 2013). Similarly, many maternal deaths recorded among this group of people can be attributed to complications arising from pregnancy and childbirth (UNFPA, 2013, p. 18-19) and female adolescents constitute a large proportion of women who undergo unsafe abortion procedures (Durojaye, 2009).

It has been observed that the SRH of women and female adolescents is repeatedly compromised by the infringement of women's human rights and not necessarily because of their lack of medical knowledge (Cook \& Fathalla, 1998). Thus, the momentum created as a result of the use of human rights to fulfil the SRH right of women (and adolescents) has continued to increase from the adoption of documents initial documents recognising protection of the right to health (Art $25 \mathrm{UDHR}$ ) to instruments and adopted in respect of same (Art 14 Women Protocol) with various governments (including Nigeria) acceding to the instruments and signifying their intention to be bound by their provisions.

The Convention on the Rights of the Child, Convention on the Elimination of all Forms of Discrimination Against Women, the International Covenant on Economic, Social and Cultural Rights, International Covenant on Civil and Political Rights, the African Charter, African Charter on the Rights and Welfare of the Child and Women Protocol etc. are treaties to which Nigeria is a signatory and from which its obligations to protect the right of adolescents to access SRHR flows. In addition to these instruments are also declarations, 
which though none binding, lend weight to the essentiality of guaranteeing adolescents access to SRHR. It is necessary to lay emphasis on the fact that that an assessment of Nigeria's obligations in the instruments is relevant especially recognising that Nigerian adolescents continue to be overwhelmed by challenges including continued high rates of unwanted pregnancies and other STIs which in turn limits their chances to economic and life improving opportunities (Ayuba \& Owoeye, 2012).

Also, considering that the Sustainable Development Goal (SDG) 3 requires that by 2030 (WHO, 2018; Galati, 2015), countries guarantee the good health and wellbeing of their citizens through universal access to SRH services, comprehensive sexuality education and the ability to make autonomous decisions about one's SRH, through an increase in contraceptive use, reduction in adolescent birth rates, reduction/end in the HIV and AIDS epidemics currently ravaging the sub-Saharan African region and thus the high levels of infection among adolescent girls etc, the importance of ensuring that the Nigerian government lives up to its obligation especially to adolescents is not debatable.

To this end, this article discusses the international recognition for the protection of SRH rights followed by an examination of the obligations and duties that arise from Nigeria's membership of the numerous international and regional treaties which guarantee the right to health (including SRH). Thereafter, the article reflects on the stance of the treaty monitoring bodies towards state parties' obligations on the right to access SRH care information and services, the position in Nigeria and some other countries. The article concludes by declaring the need for judicial activism and stricter monitoring of the government's activities in order to ensure that adolescents enjoy actual access to SRH care information and services.

\section{International Recognition for the Protection of Sexual and Reproductive Health Rights}

Recognition of the right to health derives its origin from the Universal Declaration of Human Rights (Art. 25 UDHR) and, along with other economic, social and cultural rights, is granted legal protection by the International Covenant on Economic, Social and Cultural Rights (Art. 12 ICESCR). From the outset, it is imperative to categorically state that this does not make it a lesser right entitled to minimal protection, unlike its counterparts contained in the International Covenant for Civil and Political Rights (ICCPR) as the distinction between the two sets of rights was eliminated at the World Conference with effort made to focus on the ideals behind the adoption of the Universal Declaration (De Schutter, 2010; McLean, 2009; and Alston \& Quinn, 1987). It was expressly explained that 'all rights were indivisible, universal, interdependent and interrelated' and the international community 
had an obligation to treat human rights in a fair and equal manner globally (Eide, 1995).

Moving from the right to health, the need to safeguard the SRH of women and indeed female adolescents vulnerable to SRH illnesses, through their access to SRH care services, including contraceptive information and services (WHO, 2010; Paragraph 6 General Comment 22, ICESCR Committee) prompted the initial recognition of reproductive rights as a human right during the International Conference on Human Rights held in Teheran in 1968 (Paragraph 16 Proclamation of Teheran). From this time onwards, and undoubtedly over the years, the demand for the protection of the SRH of adolescent girls has not only increased and gained international prominence, but is currently given a voice in various human rights instruments (both international and regional) that seek to recognise, guarantee and safeguard the rights of individuals, who, without the treaties, would be vulnerable (Cook, 1994-1995; Riedel, 2009).

A majority of these instruments provide for the right to health, from which the right to SRH is inferred. In some cases, provision is made for the access of women and female adolescents to sex appropriate reproductive health care services, like contraception and family planning, under the Protocol to the African Charter on the Rights of Women (Art. 14 Women's Protocol). Particularly, in relation to the right of everyone to enjoy the highest attainable standard of physical and mental health guaranteed in art 12(1) of the ICESCR, the ICESCR Committee has explained that the minimum essentials that must be satisfied by states include those of availability, accessibility, acceptability and quality (Paragraph 12 General Comment 14).

In addition to the human rights treaties protecting the right to health, the International Conference on Population and Development (ICPD); and the Beijing Women conference contributed to the recognition of women's SRH rights. While the Cairo conference laid the foundation with regards to the recognition of women's human rights as a sustainable approach towards achieving development agenda and population targets through a change of focus to individual choice and rights (ASTRA Network, 2014; Galati, 2015), the Beijing conference aided the advancement of the right of women to reproductive health by affirming that equality should be a determining factor in matters relating to sexuality and sexual relations and that issues concerning reproduction and reproductive health should be free from discrimination, coercion and violence (Paragraphs 94 \& 96 Beijing Declaration 1995; Cook \& Fathalla, 1996).

Cook and Fathalla note that the Cairo and Beijing conferences may be seen as an acknowledgment by state parties that improving women's SRH goes beyond the focus on science and health care to identifying steps that are 
to be taken by government in order to correct past injustices to women (Cook \& Fathalla, 1996, p.115).

Over the years there has been reviews of both ICPD Programme of Action (PoA) with the intention of ascertaining the level of progress that has been achieved in the protection of women's reproductive health rights and to modify the PoA where appropriate (Paragraphs 53, 54, 58 \& 70 Key Action Document; Center for Reproductive Rights (CRR), 2013). The review processes not only reveal the progress that have been accomplished, but also constantly reiterate that the commitments reached in Cairo have not been completely achieved. According to Alcalde, even though the problems and needs of the world's inhabitants have significantly changed twenty years after the PoA was approved; the issues that were causes for concern addressed in the PoA still remain (Alcalde, 2014). A similar conclusion was made at the twenty years' anniversary of the Beijing conference where it was noted that many of the same constraints that were recognised by the Beijing signatories still exist globally. In fact, it was specifically explained that while there are 'bright highlights' where progress had been made, it was unfortunate that none of the participant countries had achieved gender equality (United Nations General Assembly (UNGA) Resolution 65/234).

\section{State Obligation in Relation to Adolescents' Right to Access SRH Information and Services}

State parties are duty-bearers under international human rights law and as such, it is the norm that immediately a state assents to an international or regional treaty, it has not only agreed to be bound by the treaty but is also under the obligation to refrain from acts that would defeat the treaty's objects and purpose (Arts 2, 11 \& 18 Vienna Convention on the Law of Treaties). Despite the agreement by state parties to be equally bound by the human rights instruments assented to however, attempts were made to prioritise civil and political rights over its economic, social and cultural rights counterpart (McLean, 2009; Eide, 1995, p. 22). The efforts, as earlier noted, whilst largely unsuccessful, culminated with the adoption of the Vienna Declaration and Programme of Action (VDPA) which declared women's rights as human right and reiterated the indivisibility, universality, interdependency and interrelatedness of all human rights. The VDPA also specifically mentions that the international community has an obligation to treat all human rights fairly and equally globally (Paragraphs 5 \& 18 VDPA, 1993).

Crucial to the recognition of state responsibility in relation to the right of adolescents to access SRH care information and services is the necessity to first appreciate the four fundamental principles of the universality, inalienability, indivisibility and inter-dependency of human rights. Explaining the principle of universality, Kossen (Kossen, 2012), points out that all rights 
are universal and apply equally to all persons without discrimination. Regarding the inalienability of rights, she notes that human rights are not only inherent to all persons but also protect the foundation of human existence. Thus, it is asserted that it is impossible to sever rights from a person without threatening the significance of that existence.

On the indivisibility and inter-dependency of human rights; Kossen further explains that all rights are indivisible, equal and depend on each other. As such, it is impossible to place one right higher than the other, as a violation of one often affects several others (Kossen, 2012, p. 147-148; Heard, 1997). This position has been re-echoed by the Committee on Economic, Social and Cultural Rights, which explained on the inter-dependence of the right to health with other human rights, that the right to health is closely related to and dependent upon the realization of other human rights (Paragraphs $1 \& 3$ General Comment 14 ICESCR Committee). Hence, in order to successfully realise the right of adolescents to access SRH care services, it is important to that their rights to privacy, dignity, information and education are recognised and guaranteed (Cook, Dickens \& Fathalla, 2003, p. 159; Paragraphs 9 \& 10 General Comment 20 ICESCR Committee).

In addition, the right to SRH being an ESCR, gives rise to the general obligation of states parties' taking 'steps' that will pave the way for progressive realisation (Article 2(1) ICESCR) of rights recognised in the treaty in order to achieve their full realisation (Article 12(2) ICESCR). Although some writers have argued that the allowance given to states to take steps in Article 2(1) ICESCR permits them to exercise discretion on how and when the rights contained in the covenant are to be implemented (Alston \& Quinn, 1987; Verma, 2005), the ICESCR Committee in its general comment on the nature of states parties' obligations, specified that the ICESCR Covenant imposed two direct obligations: the obligation to observe the rights in the ICESCR without discrimination (Paragraph 34 General Comment 22 ICESCR Committee; Paragraphs 2-8 General Comment 3 ICESCR Committee) and the obligation to take steps.

In relation to the duty to take steps, states are to take 'concrete, deliberate and targeted steps' through the adoption of measures that are consistent with the nature of the rights involved with the eventual intention of achieving full realisation of their obligations under the Covenant (Coomans, 2009; Jaichand, 2010, p. 59-60). Thus, Nigeria has a responsibility while taking 'deliberate and targeted steps' to assure some minimum essentials such as ensuring access to adequate health care facilities, information and services without discrimination especially for vulnerable groups of which adolescents are one (Paragraph 43 General Comment 3 ICESCR Committee). Pertaining to the right to health, it is emphasised that the core essentials (Paragraph 12 General Comment 14 ICESCR Committee) to be assured include those of 
availability (Paragraph 14 General Comment 22 ICESCR Committee), accessibility (Paragraphs 15-19 General Comment 22 ICESCR Committee), acceptability (Paragraph 20 General Comment 22 ICESCR Committee) and quality ((Paragraph 21 General Comment 22 ICESCR Committee). In relation to adolescents' right to access to SRH care information and services, observance of the minimum essentials require that the Nigerian government set up ample youth-friendly clinics in rural and urban areas (Paragraph 30 ICESCR Committee's Concluding Observations on Russia, 2011), employ health providers with positive attitude, introduce comprehensive family life education in schools (Paragraph 27 ICESCR Committee's Concluding Observations on Moldova, 2011), enact laws that make illegal stereotypes and discrimination and also ensure that the confidentiality of adolescents are maintained when they access SRH services except where it will not be in their best interests to do so.

Apart from the general obligation to take deliberate and targeted steps, state parties also have the tripartite obligations to respect, protect and fulfil the right of adolescents to SRH care (De Schutter, 2010, p. 280). The basis for the adoption of a tripartite typology for state parties' obligation is premised on the reasoning that states are inclined towards the view that they are only under negative obligations not to abuse the rights of their citizens. This predisposition is premised on the belief that the obligation to respect places a little duty to only refrain from infringing on the rights of citizens without more; thereby making it easier to fulfil as there are no economic consideration involved. According to the Human Rights Law Resource Centre (Human Rights Law Resource Centre, 2006), using the tripartite typology to divide human rights obligations aids in highlighting the fact that state parties not only have the obligation of non-interference but also have an active role to play in the implementation of all human rights viz a viz the duty to protect and fulfil human rights.

\section{The Obligation to Respect}

The obligation to respect (Cook \& Fathalla,1998, p. 3) requires states to avoid acting in ways that prevent citizens from enjoying a guaranteed right. In relation to the right to $\mathrm{SRH}$, the obligation requires the State to refrain from supporting discriminatory practices that will affect their sexual and reproductive health status and needs'. In relation to the SRH rights of adolescent girls, the duty to respect expects that the Nigerian government not to limit or deny adolescents access to SRH, including through laws criminalising their access to SRH care services and information (Paragraph 14 General Recommendation 24 CEDAW Committee). As well, the confidentiality of the health data of users (adolescents) should be always maintained (Paragraph 40 General Comment 22 ICESCR Committee). 
According to the ICESCR Committee, the obligation to respect requires state parties to desist from intruding, either directly or indirectly (through their agents), upon the enjoyment of the right to health (Paragraph 33 General Comment 14 ICESCR Committee; Zimbabwe Human Rights NGO Forum $v$ Zimbabwe, Paragraph 152).

\section{The Obligation to Protect}

The duty to protect places a responsibility on Nigeria to take needed action to prevent non-state actors, like health providers, from hindering the access of adolescents to SRH care services and information (Paragraphs 34 \& 35 CEDAW Concluding Observations on Haiti; Ssenyonjo, 2009; Cook, Dickens \& Fathalla, 2003, p. 5-6; Paragraph 15 CEDAW General Recommendation 24; and Paragraphs 42-43 General Comment 22 ICESCR Committee). It also includes a duty of the government to adopt legislation or other measures that will enable adolescents have access to health-related services provided by third parties. In addition, it should also ensure that the privatisation of services in the health sector does not constitute a threat to the availability, accessibility, acceptability and quantity of services provided (Twinomugisha, 2015, p.22). In A.T. v Hungary, the Committee on CEDAW expounded on the obligation of state parties to protect when it stressed that states are accountable for actions committed by private actors especially where they neglect to proactively prevent, investigate and punish third parties for human rights violations.

The ICESCR Committee on the duty of state parties to protect also explained that States are obligated to ensure that adolescents have full access to appropriate information on SRH, including family planning, the dangers of early pregnancy and the prevention and treatment of STIs, including HIV/AIDS, regardless of their marital status in an environment that respects their privacy and confidentiality (Paragraph 44 General Comment 22 ICESCR Committee).

\section{The Obligation to Fulfil}

The obligation to fulfil requires the government to ensure that sufficient measures are undertaken to assure citizens of its commitment towards ensuring that their right to enjoy the highest attainable standard of health is guaranteed. To achieve this, the obligation expects government to adopt progressive legislative, budgetary and administrative measures that will positively assist all individuals (including adolescents) in all nooks and crannies of the country to enjoy the right to health (Special Rapporteur on the right of everyone to the enjoyment of the highest attainable standard of physical and mental health, 2016). 
According to the UNFPA, the key to fulfilling the right to health and therefore the right to $\mathrm{SRH}$ is to create an enabling environment through all appropriate means including through resource allocations. Particularly, states parties are to remove all legal and regulatory barriers to that impede access to health care services such as the payment of user fees for basic and emergency health services (UNFPA, 2010).

\section{Treaty Monitoring Bodies}

Essentially, all human rights treaties, both international and regional, have treaty monitoring bodies that periodically contribute to the development and understanding of human rights standards (including on the right to SRH care). The monitoring bodies issue general comments or recommendations which serve as authoritative guides on how state parties are to implement and interpret the treaties to which they are a party. In the African region, body of experts oversee the implementation of their respective human rights instruments by considering state reports, issuing general comments and also adjudicating on complaints just like their international counterparts. In some cases, general comments can either provide substantive guidance on specific provisions contained in the convention or provide general guidance that state parties are to follow (International Service for Human Rights, 2010, p. 33).

The CEDAW Committee observes that the obligation to fulfil the right to health of women (and adolescent girls) requires the Nigerian government providing gender-sensitive training for health providers in order to enable them to respond appropriately to women's SRH care needs (Paragraph 15 General Recommendation 24). To this end, the obligation to fulfil the SRH care need of Nigerian adolescents' require the government to take appropriate steps that will enable adolescents, who constitute a major part of the country's vulnerable, to not only access general health-care services but also access to appropriate SRH information and services (Paragraph 17 General Recommendation 24; Paragraph 18 General Comment 14 of the ICESCR Committee; Ssenyonjo, 2009, p. 25; and WHO Factsheet 31).

For instance, the constant failure of the government to fulfil its duty on the right of adolescents to SRH care information and services tend to cause catastrophic consequences to their SRH and therefore life, and the Human Rights Committee has interpreted that the right to life as enunciated in the ICCPR, is a 'supreme right from which no derogation is permitted even in times of public emergency which threatens the life of the nation' (Paragraph 1 General Comment 6). In relation to the right to health, the Human Rights Committee specifically points out that the right to life is often narrowly interpreted restrictively and urged state parties to ensure that their national legislations is not only in line with the provisions of the ICCPR but also adopt measures that will increase life expectancy (Paragraph 5 General Comment 6; 
Chapman, 1995; and Concluding Observations of the Human Rights Committee to El Salvador).

The failure of adolescents to access SRH information and services accounts for high maternal mortality and morbidity rates and is a violation of their right to life. In calculating maternal mortality rates, deaths resulting from the abortion of unwanted pregnancies and teenage pregnancies are usually factored in and Nigeria's maternal mortality rate of 814 for every 100,000 live births is the fourth highest in the world and adolescent girls contribute largely to it (WHO, UNICEF, UNFPA, World Bank Group, and United Nations Population Division, 2015; Bankole, Sedgh, Okonofua, Imarhiagbe, Hussain \& Wulf, 2009; Ujah, Aisien, Mutihir, Vanderjagt, Glew \& Uguru, 2005). Where a state fails to guarantee its adolescents (especially adolescent girls) access to contraceptive information and services or other reproductive health services needed by women generally, the right to life is violated (Paschim Banga Khet Mazdoor Samity \& Ors V. State of West Bengal \& Anor).

Taking into cognisance the comment of the Human Rights Committee that effort should be made to avoid the narrow interpretation of the right to life, it is argued that the protection of the right to life imposes a duty upon the Nigerian State to provide access to youth-friendly health services through which adolescents' can easily access information and services relating to SRH so as not to place their lives in jeopardy (Attahir, Sufiyan, Abdulkadir \& Haruna, 2010; Akani, Enyindah \& Babatunde, 2008; and Idonije, Oluba \& Otamere, 2011).

Understanding the importance of the right to non-discrimination, the ICESCR Committee clarified that states have an obligation to eliminate discrimination in all 'guises', both formally and substantively, in order to ensure that the Covenant rights are enjoyed equally (Paragraphs 8 \& 9 General Comment 20). Explaining that while article 2(2) of the ICESCR lists prohibited grounds of discrimination, including race, colour, sex, birth, it also includes 'other status' which denotes that the list is not exhaustive as other grounds such as age and marital status, prominent grounds upon which adolescent girls are denied access to SRH care services, can be added to it (Paragraphs15, 27, $29 \& 31$ General Comment 20). Thus, in line with the ICESCR Committee's interpretation in its General Comment 14 (Paragraphs 47-52), adolescents' right to access SRH care is violated where the government adopts policies and laws that bar them from accessing essential information on the availability of contraceptive services and other reproductive health services. Also, the government is in breach of its obligation where its health providers deliberately withhold information from adolescents that the use of family planning assists in the prevention of teenage pregnancies and STIs or where their accessibility to contraception is impeded due to the privatisation of health care services without providing alternatives 
where the services can be obtained (Paragraph 35 General Comment 14 ICESCR Committee).

Reiterating its position on the necessity to guarantee access to SRH care information and services, the ICESCR Committee in its General Comment 22 maintained that the right to $\mathrm{SRH}$ is an integral part of the right to health as enshrined in article 12 of the ICESCR and the full enjoyment of the right remains a distant goal for millions of people, especially adolescents as a result of barriers that restrict access to the full range of SRH facilities, services and information (Paragraphs 1 \& 2; Savage-Oyekunle, (2015); and Savage-Oyekunle \& Nienaber, 2015). Thus, the Committee stressed that states' duty to ensure the enjoyment of the right to SRH care extends beyond their just guaranteeing ordinary access to SRH care information and services to include addressing underlying social determinants that not only have a negative impact on the right to $\mathrm{SRH}$ but also prevent individuals from effectively enjoying in practice their SRH (Paragraphs 7 \& 8 General Comment 22 ICESCR Committee).

The Committee on the CRC noting that states have been neglectful in protecting the rights of adolescents to access SRH care information and services provides guidance that state parties can utilise in furthering efforts to guarantee the realisation of the right to SRH of adolescents (CRC Committee General Comments $3 \& 4$ ). The committee urges states to ensure that appropriate services and information for the prevention and treatment of STIs, HIV and AIDS are available and accessible to adolescents. It also asked for the removal of barriers which hinder adolescents access to SRH information (Paragraphs 24 \& 26 General Comment 4 CRC Committee). Also, considering the evolving capacities of children, states are encouraged to ensure that only trained providers who respect the rights of adolescents to confidentiality render SRH care services to them (Paragraph 17 General Comment 3 CRC Committee). It is necessary state that recognition of the right of adolescents in the country to SRH information and services, entails their having access to private and confidential consultations with health providers once it has been confirmed that they are Gillick competent (Gillick v. West Norfolk and Wisbech Area Health Authority and Another) and it will be in their best interests to do so (Paragraph 1 General Comment 14 CRC Committee).

The CRC committee emphasises that the opinion of adults on what is perceived to be in the child's best interests should not override the states' obligation to respect rights guaranteed under the Convention as all rights guaranteed in the CRC including the right to the highest attainable standard of health and also the right to SRH care information and services, are in the 'child's best interests' and none of the rights should be negatively construed (Paragraph 24 General Comment 15 CRC Committee). According to the committee, the rationale for developing general comment 14 is based on the 
need to strengthen understanding and application of the right of children to have their best interests assessed and taken as a primary consideration so as to engineer real change in attitude that will result in the respect of children as rights holders (Paragraphs 4, 11 \& 12 General comment 14 CRC Committee; Lansdown \& Wernham, 2012).

The African Commission in its general comments on article 14(1)(d) and (e) of the Women Protocol, interpreted that the right to self-protection and to be protected includes the right of women and adolescent girls to access relevant SRH information and services. It therefore mandates state parties to live up to its obligation of creating an enabling environment that will fully empower the realisation of the right (Paragraphs $10 \& 11$ General Comment on Article 14(1)(d) and (e) of the Women Protocol). Also, in its General Comment No. 2, states are not only required to remove the impediments but also provide accurate information necessary for the respect, protection and fulfilment of the right to SRH of adolescents while ensuring availability, quality, financial and geographical accessibility of the SRH care services without any form of discrimination (Paragraphs 26-29 General Comment No. 2 on Article 14.1 (a), (b), (c) and (f) and Article 14. 2 (a) and (c) of the Women Protocol).

\section{The Position in Nigeria}

Nigeria being a party to the numerous human rights treaties and declarations guaranteeing the right to health care and other associated rights relevant to its protection should realise that successful transition to adulthood entails the satisfaction of several requirements including ensuring its adolescents' access to health promoting information, and youth-friendly SRH care services. Thus, ensuring that adolescents enjoy their right to SRH care generally and SRH information and services in particular, requires the government fulfilling and discharging the obligations which arise as a result of it being a party to the numerous human rights instruments protecting the right to health.

In relation to the recognition and protection of the right of adolescents to access SRH care information and services, the Nigerian Constitution, 1999 recognises the right to life, dignity, privacy, non-discrimination and the right to freedom of expression and information (Sections 33, 34, 37, 42 \& 39). However, while the Constitution provides for the above rights from which the right of adolescents to SRH care can be inferred, it does not contain any specific provision in chapter four granting recognition for the protection of the right to health, nor does it recognise the right to reproductive health which is of paramount importance to adolescents, as a directly enforceable right. Instead, section 17(3) on the fundamental objectives and directive principles merely directs the State to direct its policy towards ensuring that the health of 
its citizens is safeguarded and that there are 'adequate' medical and health facilities for all. Unfortunately to ensure that the government lives up to this objective, the judicial powers of the law courts is ousted in section 6(6)(c), thus making the contents of chapter two unenforceable. This is particularly worrisome especially given the reality as Durojaye notes that litigation provides a genuine catalyst for a change in the law and can be utilised to hold the Nigerian government answerable for its failure to fulfil its responsibilities on the right to health (Durojaye, 2010a).

As a result of Nigeria's failure to fulfil its obligations to adolescents especially in relation to their right to access SRH care, adolescents in the country repeatedly encounter challenges in accessing important SRH care information and services although they are largely involved in pre-marital sexual activities either as a means to alleviate economic hardship or due to the need to satisfy their curiosity/peer pressure (Singh \& Darroch, 2012; Attahir, Sufiyan, Abdulkadir \& Haruna, 2010, p. 15-20). Research on adolescent SRH continually reveal that adolescents are often misguided about reproduction (UNITED NATIONS, 2003; Arowojolu, Ilesanmi, Roberts \& Okunola, 2002). This is coupled with the stereotype of health care workers, negative cultural and societal perceptions about contraceptive and other SRH services use (Omo-Aghoja et al, 2009; Kinaro, 2011). Often times, institutionally imposed barriers such as the imposition of the payment of user fees for services provided at government hospitals and privacy issues also impede adolescents access and use of SRH services.

The above factors result in adolescent girls accounting for a large proportion of hospital admissions arising from abortion complications (Tayo, Akinola, Babatunde, Adewunmi, Dele Osinusi \& Shittu, 2011), an adolescent fertility rate that is estimated as 104 live births per 1,000 births (World Bank, 2017), vulnerability to diverse STIs, including HIV (Mmari, 2010) and contribute to the high maternal mortality rates in the country. Estimates put the Maternal Mortality Rate in Nigeria at 814 for every 100,000 live births, the fourth highest in the world (WHO, UNICEF, UNFPA, World Bank Group, and United Nations Population Division, 2015; Bankole, Sedgh, Okonofua, Imarhiagbe, Hussain \& Wulf, 2009, p. 3; and Ujah, Aisien, Mutihir , Vanderjagt, Glew \& Uguru., 2005). According to the WHO, adolescents make up a significant segment of people that are vulnerable to HIV as 50\% of HIV transmission takes place among those aged 15-24 (WHO, 2006, p. 2). Likewise, the UNICEF in its analysis of UNAIDS in 2013, notes that over 196,000 adolescents, who make up a staggering 10 percent of the global burden, are living with HIV/AIDS in Nigeria with a lot of AIDS-related deaths occurring among the age group (Ejembi, 2016).

The above statistics which reveals a failure of the Nigerian government to live up to its commitment on the right to health care, brings to the fore the 
necessary to take steps in order to make the government accountable for its failure to adequately protect the right of vulnerable adolescents to SRH care information and services. However, making the government accountable for its obligations on the right to health as earlier noted comes with its attendant problems which is premised on the fact that, health is only mentioned in chapter 2 under the fundamental objectives and directive principles of state policy in section $17(3)(\mathrm{d})$ which is rendered non-justiciable by the provisions of section 6(6)(c) which ousts the jurisdiction of national courts from adjudicating on matters relating to the non-performance by government of its obligations under chapter 2 , thereby making the provisions merely declaratory (AG Ondo v A G Federation).

On their part, Okeke and Okeke (Okeke \& Okeke, 2013), explain that it is unlikely that the provisions contained in chapter 2 of the Constitution were intended to make the government assume responsibility since the jurisdiction of the courts that should naturally assist in ensuring accountability, has been ousted as a result of the non-justiciability clause. Irrespective however, it is opined that neither the failure to provide a constitutional guarantee for the protection of the right to health nor the making of the provisions of section 17(3)(d) non-justiciable, discharges the government from its duty to ensure that adolescents are guaranteed access to SRH information and services. This view is based on several grounds:

First, despite that the ICESCR, does not have legal force in Nigeria as a result of its non-domestication as recommended in section 12 of the Constitution, the African Charter on Human and Peoples' Right, particularly article 16 which protects the right to health, has been domesticated as a national legislation through the African Charter on Human and Peoples, Rights (Ratification and Enforcement) Act and as explained by the Supreme Court in Abacha v Fawehinmi; the provisions contained in the African Charter Act are provisions in a class of their own, protected by international law and thus cannot be overridden by other municipal laws. As a result, it is possible for the law courts to rely on its provisions to ensure that the Nigerian government meets its obligation to respect, protect and fulfil the SRH right of adolescents.

Also, even though the objectives and principles on health, like other contents of chapter two of the Constitution have been declared unenforceable by virtue of section $6(6)(c)$, it is believed that going by the provisions of section 13 of the Constitution, which declares that 'it shall be the duty and responsibility of all organs of government to conform, observe and apply the provisions contained in the fundamental objectives and directive principles', the requisite organs of government have a responsibility to act in good faith in performing their duties in order for the ideals expressed in Chapter 2 of the Constitution to be achieved. In Nwankwo v Yar Adua, the court interpreted 
that the word 'shall' imports a command or mandate that must be done (Enwezor v INEC; Ngige v. Obi), thus, the fact that there are numerous health policies (National Health Policy 2004; National Reproductive Health Policy 2001 \& National Youth Policy) on the right to access health care, including on SRH, creates an important duty for the government to ensure that the contents of the policies become achievable, thereby realising its human rights obligation in respect of adolescents right to access SRH care.

Instead of Nigerian courts declaring their helplessness to enforce the contents of chapter 2 due to the provisions of section 6(6)(c), they can proactively use every opportunity to give 'judicial support' by dissecting and analysing laws which relate to the right to health or have an impact on it in order to declare government actions or inactions incompatible with the right to health where applicable. In this instance, the courts can take judicial notice of international and regional human rights instruments brought to the courts' attention. For example, the Fundamental Rights Enforcement Procedure Rules (FREP Rules), in its preamble provides that 'the court shall conscientiously seek to give effect to the overriding objectives of the rules at every stage of human rights action for the purpose of advancing an applicant's rights and freedoms with the court respecting municipal, regional and international bills of rights brought to its attention' (Preamble 3 FREP Rules, 2009).

In addition, just like the Indian courts, which has adopted a stance of judicial activism (Paschim Banga Khet Mazdoor Samity \& Ors v State of West Bengal \& Anor) to enforce protection of the right to health through a purposeful linking with the right to life in Article 21, fundamental human rights already recognised in the Nigerian Constitution (Sections 33, 34, 37 \& 39) are good grounds through which the aim of ensuring protection for the SRH of adolescents can be achieved. Some Nigerian courts have adopted this proactive posture as seen in Gbemre v Shell Petroleum Development Company and Others and Georgina Ahamefule v Imperial Medical Center \& Alex Molokwu. In the Ahamefule's case, the plaintiff, who was as an employee nurse at the Imperial Medical Center, developed a boil on her skin during pregnancy and decided to seek medical attention at her employer hospital. While seeking treatment, several tests were conducted on her by the defendant without her knowledge or informed consent. She was also not given information about the results from the tests but was rather referred to the Lagos University Teaching Hospital after being given two weeks leave. it was at the teaching hospital that the plaintiff was informed after further tests that she had tested positive for HIV. Upon her return to her employer hospital, her employment was abruptly terminated and owing to the unexpected termination and the shock of learning about her positive status, the plaintiff lost her pregnancy and also constant suffered rejection and humiliation from the defendants. 
The plaintiff thereafter instituted an action that the termination of her employment due to her HIV status was not only unlawful but also constituted unfair discrimination contrary to the provisions of the African Charter as domesticated in Nigeria. After several hearings, the court held that a violation of the right to health was also a violation of the right to life under section 33 of the Constitution and article 16 of the African Charter. Considering that inaccessibility to SRH information and services results in greater negative consequences for adolescents generally and female adolescents in particular, the courts are enjoined reflect on this factor in actions relating to the violation of the right SRH care and pronounce that the failure by the government to live up to its obligation to ensure the respect, protection and fulfilment of the right to SRH is also a violation of its obligation on the right to life (Durojaye, 2010b).

As already noted, in addition to the challenge posed by the nonrecognition of the right to health in the Constitution and the attendant issue on its justiciability, another difficulty which impedes application of the right to health and SRH in Nigeria relates to the fact that the mere ratification of a treaty does not guarantee its direct implementation in the country as there is still need for domestication by the National Assembly (Section 12 Nigerian Constitution, 1999). Thus, even though the various conventions guaranteeing the right to health has been ratified by Nigeria, only the African Charter, Convention on the Rights of the Child and African Charter on the Rights and Welfare of the Child which have been domesticated as local legislation apply directly in the country. Unfortunately, however, in relation to the right of children to privacy (Section 8), the CRA which should be a tool in furthering adolescents access to confidential SRH care services contains a restrictive provision which may dissuade adolescent girls from accessing the required services thereby exposing them to the risks occasioned by engaging in unprotected sexual relations.

Section 8 (1) and (2) of the CRA provides that 'nothing in the section and sub-section shall affect the rights of parents to exercise reasonable supervision and control over the conduct of their children and wards'. This provision while trying to preserve the authority of parents over the wards in all situations does not take cognisance of the evolving capacities and best interests of adolescents who will rather engage in unprotected sexual activities than risk their parents' involvement in their attempt to access SRH care services (Cook, Dickens \& Fathalla, 2003, p. 167; Cook \& Dickens B, 2000; and CRR \& UNFPA, 2010). This may also be regarded as a failure of the government of its obligation on the right to health as the issues of privacy and confidentiality is germane to adolescents' enjoyment of their right to SRH.

In 2014, the Nigerian National Health Act was signed into law. The Act which is based upon the move to adopt a comprehensive health legislation 
that will assure access to basic health care services not only defines clear roles and responsibilities for all the levels of government but also provides a framework for the effective planning, financing, monitoring and general evaluation of health care services (Sections $1 \& 3(2)(\mathrm{d})$ ). Apart from including provisions for making accessible to patients' relevant information on their health status (Section 23 (1)), the National Health Act provides that patient's privacy and confidentiality is maintained at all times except in situations where it will be impossible to do so (Section 26). Generally, based on its contents, the enactment of the Act is a step in the right direction, especially for female adolescents who suffer untold humiliation in the hands of health providers when seeking to access SRH care services.

Infact, with the enactment of the Act, it is argued that violations of the right to health are now justiciable due to the reason that the National Assembly has enacted a specific law for the protection and enforcement of a Chapter two provision - the right to health. This position is hinged upon the declaration of the Supreme Court in Attorney General Ondo v Attorney General Federation, where it explained that the contents of Chapter Two of the Nigerian Constitution remain merely declaratory and cannot be enforced by legal process unless they are validated by legislation and every opportunity should be used to 'push' the government to live up to its duty.

In relation to its obligation to give account through the rendering of state reports to the appropriate monitoring bodies, Nigeria has to some extent complied with this mandate. For instance, Nigeria submitted its combined third and fourth periodic report to the Committee on the Rights of the Child in 2008. In its concluding observation to Nigeria's report, the CRC Committee, apart from advocating that the right of the child to the best attainable state of physical and mental health is constitutionally recognised (Paragraph $60(\mathrm{e}) \&(\mathrm{f})$ ), also recommended the abolishment of user fees and the implementation of child/adolescent friendly awareness programmes on adolescents use of SRH care services (Paragraphs 27 \& 62). Also recognising the power held by traditional authorities in their individual communities, the Committee strongly recommended that the Nigerian state should identify strategies to formally engage traditional and religious leaders in ensuring implementation of the Convention rights at local level as this will go a long way in assisting it fulfil its obligations in relation to adolescents' access to SRH care (Paragraphs $10 \& 11)$. Furthermore, the Committee, referring to the recommendations by the Committee on the CEDAW, urged the government to as a matter or priority, to expand efforts to ensure community participation in issues relating to maternal health, child health and family planning and also note the correlation between access to health care and education, with a view to combat maternal mortality and empower women (including female adolescents) in decision making concerning their health care (Paragraphs 60 
(d) \& (e)). In addition to the above, the CEDAW Committee in its concluding observation to Nigeria's report also called upon the government to not only respect adolescent right to SRH care by increasing their access to SRH information but also make efforts to improve the availability, affordability and accessibility of SRH care services, particularly at the primary health care level and in rural areas.

Apart from reporting to internal treaty monitoring bodies, Nigeria also submits state reports to the monitoring bodies in the African region; the African Commission on Human and Peoples' Rights and the African Committee of Experts on the Rights and Welfare of the Child. In its concluding observation on Nigeria's third report, the African Commission, expressed worry at the high incidence of maternal mortality and also requested information on whether the National HIV and AIDS Policy provides the necessary medical care in preventing mother to child transmission of HIV. The two issues raised by the African Commission are a focal point where the government is failing in its duty to protect especially, especially adolescent girls who are highly affected by the AIDS epidemic and maternal mortality (Paragraph 24 Concluding Observations and Recommendations on Third Periodic Report of Nigeria, 2008). In its concluding observations to the country's fifth report, the Commission urged Nigeria to strengthen ongoing initiatives to reduce the high rate of maternal mortality by eliminating all barriers to maternal health services and improve access to contraceptives and other SRH options. In addition, Nigeria was advise to revise its law on abortion in order to bring it in line with the Women's Protocol and other international human rights standards (Paragraphs 117 \& 118 Concluding Observations and Recommendations on Fifth Periodic Report of Nigeria, 2015).

On its own part, the Committee of Experts to the ACRWC in its concluding recommendation has severally noted that the Child Right Act is only applicable in 24 states and not throughout the country. It recommends that the government takes further resolute steps to encourage consistent implementation of the Act in states (Paragraphs $1 \& 2$ ). It is felt that with persistence and perseverance, the Nigerian government will be successful in breaking barriers which affect its ability to fulfil its duty to adolescents in relation to the enjoyment of their SRH rights.

Finally, while it can be said that Nigeria is endeavouring to comply with its obligations under the numerous treaties guaranteeing the right to SRH care, it can still be said that its compliance to its obligations remains a constant struggle, as sometimes, state reports that are to be submitted to the human rights committees end up being delayed unnecessarily. In addition, cultural, religious and systemic barriers are impediments that continue to affect adolescents access to SRH care, hence revealing that the government is still 
lacking in its duty to effectively respect, protect and fulfil the right of adolescents to access SRH care.

\section{Global Situation}

As already known, adolescents' capacity to make autonomous decisions regarding their SRH is generally confined by cultural, social and institutional impediments which prevent them from accessing SRH care services and information. Thus, it is necessary to emphasise that governments in other countries also have the obligation to respect, protect and fulfil the rights of adolescents to access important SRH care information and services without fear or stigmatisation. Despite the foregoing however, just like in the case of Nigeria, adolescents accessing affordable and readily available SRH services in several states remain a challenge (Savage-Oyekunle \& Nienaber, 2017).

In Kenya for instance, the National Commission on Human Rights noted that inaccessibility to comprehensive family planning and other SRH care services is a common obstacle experienced by adolescents and youths in Kenya despite the various regional and international institutional frameworks to which Kenya is a party, and the existence of several national legislations and policies (Ipas Africa, 2016; Kenya National Commission on Human Rights, 2012). Notwithstanding the recognition of the right to the highest attainable standard of health, which includes the right to SRH care services in its constitution (Article 43 Kenya Constitution, 2010), the existence of cultural and religious impediments/gatekeepers still prevent the dissemination of realistic SRH information to adolescents revealing the failure of the government to fulfil its obligation to protect the right of its adolescents to access SRH care information from abuse by third parties (Oronje, 2013).

The situation is no different in Zimbabwe as adolescents' access to SRH care information and services is curtailed by several factors including, but not limited to the entrenchment of taboos about adolescent sexuality, the failure of the government to provide access to in-depth sexuality information/education, the high cost of contraceptives and the existence of inconsistent laws and policies on the appropriate age when adolescents can give consent to access SRH care services. The existence of these influences contributes substantially to the high rate of adolescent pregnancy, HIV and maternal morbidities experienced in the country. According to Amnesty International, the situation reveals a case of failure by the government to meet its human rights obligations to protect the SRH rights of adolescents (Amnesty International, 2018).

In the United States, it has been stated that regardless of the decline in adolescent pregnancy rates over the past few decades, the country still has one of the highest rates of adolescent pregnancies in the developed world 
(Mermelstein \& Plax, 2016; Centers for Disease Control and Prevention, 2015). The gains recorded in reducing adolescent pregnancy rates which may be attributed to several efforts such as increased awareness about SRH among adolescents (Editor's choice, 2015) and the empowerment of School-Based Health Centres, who provide adolescents with contraceptives and other SRH services from funding received from federal grant programs including those authorised under the Affordable Care Act (ACA) has however not been without its challenges (Boonstra, 2015). A particular challenge mentioned is that while the enactment of the ACA has made it possible for adolescents and young adults to be covered under their parents' or guardians' health insurance plan in order to improve their access to quality care; this comes with the attendant problem of lack of confidentiality which as Fuentes (Fuentes, ${ }^{2017)}$ and others (Frerich, 2010) note result in adolescents not accessing contraception and other SRH care services due to the fear that details of the services rendered to them will be disclosed to the policy holder thus eroding the gains that may be fully achieved by providing access to SRH in private.

Currently, fears of losing the gains made in recent years are heightened because of policy somersaults which saw the rescission of federal requirement that employers must include birth control coverage in their insurance plans and restoring the global gag rule among others. The new measures to clamp access to birth control and other SRH care services range from allowing employers refuse to provide insurance coverage for contraception on religious or moral grounds to blocking access to grants for health care providers who offer contraceptives and other related health care services (CRR, 2017a). While application of the policy restricting access to contraception as a result of religious and moral objections is being challenged in the law courts (CRR, $2017 \mathrm{~b}$ ), it is necessary to reiterate that the restriction of access to contraceptives for adolescents and women in general is a failure by the American state to not only fulfil its obligations to provide available, accessible, affordable and quality health care services for all but also protect the right of adolescents to SRH care by preventing third parties from performing acts that infringe the right.

\section{Conclusion}

It is not enough that Nigeria keeps acceding to every human right treaty or instrument that becomes available for ratification, both internationally and regionally. Instead, the government needs to show greater commitment towards fulfilling the responsibilities created by instruments already ratified. The ratification of treaties, though steps in the right direction, still has gaps, as existing evidence revealing that Nigerian adolescents still experience poor SRH outcomes abound (UNFPA, 2011; Mmari, 2010). Thus, revealing the need for the government to put in place more appropriate structures that will 
improve and guarantee young people's access to SRH care information and services in fulfilment of its obligations on the right to health in generally and SRH in particular.

Mechanisms used in evaluating whether government's action conforms with their commitment to protect and promote adolescents access to SRH care information and services need to be consistently improved upon. Hence, there is need for Civil Society Organisations (CSOs) to be proactive in scrutinising strictly, government's actions towards realising its obligations on adolescents' SRH by submitting shadow reports to the treaty bodies whenever Nigeria is to submit its state report. Also, there is need for Nigeria to embrace actively its use of monitoring tools such as human rights indicators, benchmarks and indices without which, it will be a challenge to determine whether its 'compliance' or 'progress' is real or merely on paper.

In addition, Nigeria needs to show more commitment towards fulfilling is state obligation of assuring adolescents access to SRH information and services by for example, urgently setting up adolescent-friendly clinics all over the country as done in other jurisdictions. When adolescents have their space to confidentially seek information and access SRH care services, adolescent SRH in the country will hugely improve.

This article concludes by declaring the constant need for judicial activism by domestic courts in order to keep the government on its toes and 'alive' to its obligations. The brave stance of domestic courts in holding the Nigerian government and third parties liable for a breach of the right to life provisions in the constitution and right to health provisions under the domesticated African Charter is commendable. It is recommended that the courts should go further, by assisting in assuring the guarantee of female adolescents' right to access SRH care information and services through a purposive interpretation of a duty to provide access to confidential and safe SRH care services from the right to life, dignity, non-discrimination and information as guaranteed in Chapter four of the Nigerian Constitution.

\section{References:}

1. AG Ondo v A G Federation, (2002) 9 NWLR (Pt 772) 272.

2. Akani, Enyindah \& Babatunde (2008). Emergency contraception: knowledge and perception of female undergraduates in the Niger-Delta of Nigeria. Ghana Medical Journal Vol. 42. 68-70.

3. Alcalde, (2014). Is 20 years just nothing? ICPD 20 years after its adoption. Retrieved from https://www.ippfwhr.org/en/news-room/is20-years-just-nothing-icpd-20-years-after-its-adoption (31 March 2016). 
4. Alston \& Quinn, (1987). The nature and scope of states parties' obligations under the International Covenant on Economic, Social and Cultural Rights. Human Rights Quarterly. Vol 9, 156 - 229.

5. Amnesty International (2018). Lost without knowledge: Barriers to sexual and reproductive health information in Zimbabwe. Retrieved from https://www.amnesty.org/en/documents/afr46/7700/2018/en/(17 February 2018).

6. Abacha v Fawehinmi, (2000) 6 NWLR (Pt 660) 228.

7. Arowojolu, Ilesanmi, Roberts \& Okunola, (2002). Sexuality, contraceptive choice and AIDS awareness among Nigerian undergraduates. African Journal of Reproductive Health. Vol. 6, 6070.

8. ASTRA Network. (2014). Reclaiming and redefining rights: Setting the Adolescent and Young People SRHR Agenda Beyond ICPD+20. Retrieved from http://www.astra.org.pl/repronews/98-newpublication-reclaiming-and-redifiniting-the-adolescent-and-youngpeople-srhr-agenda-beyond-icpd-20.html (17 March 2014).

9. Attahir, Sufiyan, Abdulkadir \& Haruna, (2010). Knowledge, perception and practice of emergency contraception among female adolescent hawkers in Rigasa sub-urban community of Kaduna State Nigeria. Journal of Family and Reproductive Health Vol. 4, 15-20.

10. Ayuba \& Owoeye, (2012). Outcome of teenage pregnancy in the Niger-delta of Nigeria. Ethiopian Journal of Health Sciences Vol. 22, 46.

11. Bankole \& Malarcher, (2010). Removing barriers to adolescents' access to contraceptive information and services. Studies in Family Planning Vol. 41, 117.

12. Bankole, Sedgh, Okonofua, Imarhiagbe, Hussain \& Wulf, (2009). Barriers to Safe Motherhood in Nigeria, pg. 3. Retrieved from http://www.guttmacher.org/pubs/2009/05/28/MotherhoodNigeria.pdf (20 March 2016).

13. Beijing Declaration, (1995). U.N. Doc. A/CONF.177/20 (1996).

14. Boonstra, (2015). Meeting the Sexual and Reproductive Health Needs of Adolescents in School-Based Health Centers. Guttmacher Policy Review. Retrieved from https://www.guttmacher.org/sites/default/files/article_files/gpr180211 5.pdf (16 February 2018).

15. Centers for Disease Control and Prevention (2015). Teen Pregnancy in the United States. Retrieved from https://www.cdc.gov/teenpregnancy/about/index.htm (16 February 2018). 
16. General Comment 14 ICESCR Committee. Retrieved from http://www.refworld.org/pdfid/4538838d0.pdf (16 February 2018).

17. Chapman, (1995). Monitoring women's rights to health under the International Covenant on Economic, Social and Cultural Rights. American University Law Review Vol. 44, 1171.

18. Child Rights Act (CRA) Cap C50 LFN 2004.

19. Concluding Observations and Recommendations on Fifth Periodic Report of Nigeria, (2015). Retrieved from http://www.achpr.org/files/sessions/57th/conc-obs/5th-2011-

2014/concluding_observations_nigeria_5th_sr_eng.pdf (5 January 2018).

20. Concluding Observations and Recommendations on Third Periodic Report of Nigeria, (2008). Retrieved from http://www.achpr.org/files/sessions/44th/conc-obs/3rd-2005-

2008/achpr44_conc_staterep3_nigeria_2008_eng.pdf $\left(8^{\text {th }}\right.$ October 2013).

21. Concluding Observations of the CRC Committee on Nigeria, (2010). Retrieved from http://daccess-ddsny.un.org/doc/UNDOC/GEN/G10/431/92/PDF/G1043192.pdf?Open Element (25 October 2017).

22. Concluding Observations of the CRC Committee on Nigeria, (2010). Retrieved from http://daccess-ddsny.un.org/doc/UNDOC/GEN/G10/431/92/PDF/G1043192.pdf?Open Element (25 October 2017).

23. Concluding Observations of the Human Rights Committee to El Salvador, UN Doc CCPR/CO/78/SLV 14.

24. Retrieved from http://www.nigerialaw.org/ConstitutionOfTheFederalRepublicOfNigeria.html (5 March 2016).

25. Cook \& Dickens, (2000). Recognizing adolescents' 'evolving capacities' to exercise choice in reproductive healthcare. International Journal of Gynaecology \& Obstetrics Vol. 70, 1.

26. Cook \& Fathalla, (1998). Duties to implement reproductive rights. Nordic Journal of International Law Vol.67, 1.

27. Cook \& Fathalla, (1996). Advancing reproductive rights beyond Cairo and Beijing. International Family Planning Perspectives Vol. 115.

28. Cook, (1994-1995). Human rights and reproductive selfdetermination. American University Law Review Vol. 44, 977.

29. Coomans, (2009). The International Covenant on Economic, Social and Cultural Rights: From step child to full member of the human rights family. In Felipe \& de Feyter (eds)., International human rights law in a Global Context (Universidad de Deusto). 
30. CRR \& UNFPA, The Right to Contraceptive Information and Services for Women and Adolescents (2010). Retrieved from http://www.unfpa.org/webdav/site/global/shared/documents/publicati ons/2011/Contraception.pdf (26 October 2012).

31. CRR, (2013). ICPD and human rights: 20 years of advancing reproductive rights through $U N$ treaty bodies and legal reform 1. Retrieved from http://www.unfpa.org/sites/default/files/pubpdf/icpd_and_human_rights_20_years.pdf (27 March 2016).

32. CRR, (2017a). President Trump Signs Measure Reversing Obama Era Rule Protecting Women's Access to Basic Health Care. Retrieved from https://www.reproductiverights.org/press-room/president-trumpsigns-measure-reversing-obama-rule-protecting-women-access-tohealth-care ( 17February 2018).

33. CRR, (2017b). Center for Reproductive Rights to Fight Back in Court After Trump Administration Guts Women's Access to Birth Control. Retrieved from https://www.reproductiverights.org/press$\mathrm{room} /$ center-for-reproductive-rights-to-fight-back-in-court-aftertrump-administration-guts-wom (17 February 2018).

34. De Schutter, (2010). International human rights law: Cases, materials and commentary. Cambridge: Cambridge University Press).

35. Dehne \& Riedner, (2005). Sexually transmitted infections among adolescents: The need for adequate health services, pg. 1. Retrieved from http://whqlibdoc.who.int/publications/2005/9241562889.pdf (17 October 2015).

36. Durojaye, (2009). Realizing access to sexual health information and services for adolescents through the Protocol to the African Charter on the Rights of Women. Washington and Lee Journal of Civil Rights and Social Justice Vol.16, 137.

37. Durojaye, (2010a). Litigating the right to health in Nigeria: Challenges and prospects. In M Killander (ed)., International law and domestic human rights litigation in Africa. (Pretoria: PULP Press).

38. Durojaye, (2010b) Realising access to contraception for adolescents in Nigeria: A human right analysis. University of Free State.

39. Editor's choice (2015). Realizing reproductive health equity for adolescents and young adults. American Journal of Public Health. Vol $10,1284$.

40. Eide, (1995). Economic, social and cultural rights as human rights. In A. Eide et al (eds), Economic, social and cultural rights: A textbook (Martinus Nijhoff Publishers).

41. Ejembi, (2016 June 10) 196,000 adolescents living with HIV/AIDS in Nigeria -UNICEF'. The Sun Retrieved from 
http://sunnewsonline.com/196000-adolescents-living-with-hivaids-innigeria-unicef/ (27 December 2017).

42. Enwezor v INEC (2009) 8NWLR (Pt 1143) 223 CA.

43. Frerich (2010). Health Care Reform and Young Adults'Access to Sexual Health Care: An Exploration of Potential Confidentiality Implications of the Affordable Care Act Retrieved from https://www.ncbi.nlm.nih.gov/pmc/articles/PMC3490669/pdf/AJPH. 2012.300857.pdf (15 February 2018).

44. Fuentes (2017). Adolescents' and Young Adults' Reports of Barriers to Confidential Health Care and Receipt of Contraceptive Services. Journal of Adolescent Health Vol. 62. Retrieved from https://www.researchgate.net/publication/321172740_Adolescents'_a nd_Young_Adults'_Reports_of_Barriers_to_Confidential_Health_Ca re_and_Receipt_of_Contraceptive_Services (15 February 2018).

45. Fundamental Rights Enforcement Procedure Rules (FREP Rules) 2009 retrieved from http://www.refworld.org/pdfid/54f97e064.pdf (28 November 2017).

46. Galati (2015). Onward to 2030: Sexual and reproductive health and rights in the context of the sustainable development goals. Retrieved from https://www.guttmacher.org/gpr/2015/10/onward-2030-sexualand-reproductive-health-and-rights-context-sustainable-development (27 December 2017).

47. Gbemre v Shell Petroleum Development Company and Others, (2005) Suit No. FHC/B/CS/53/05 (unreported).

48. General Comment 22 (2016) of the ICESCR Committee on the right to sexual and reproductive health. Retrieved from https://www.escrnet.org/resources/general-comment-no-22-2016-right-sexual-andreproductive-health (23 November 2017).

49. General Comment 3 (1990) of the ICESCR Committee on the nature of States parties' obligations. Retrieved from http://www.refworld.org/docid/4538838e10.html ( 23 November 2017).

50. General Comment 3 of the CRC Committee on HIV/AIDS and the rights of the child. Retrieved from http://www.refworld.org/docid/4538834e15.html (23 November 2017).

51. General Comment 31 Human Rights Committee on the nature of the general legal obligation imposed on states parties to the Covenant. Retrieved from http://docstore.ohchr.org/SelfServices/FilesHandler.ashx?enc=6QkG 1d\%2FPPRiCAqhKb7yhsjYoiCfMKoIRv2FVaVzRkMjTnjRO\%2Bf ud3cPVrcM9YR0iW6Txaxgp3f9kUFpWoq\%2FhW\%2FTpKi2tPhZs 
bEJw\%2FGeZRASjdFuuJQRnbJEaUhby31WiQPI2mLFDe6ZSwM MvmQGVHA\%3D\%3D (23 November 2017).

52. General comment 4 of the CRC Committee on adolescent health and development in the context of the Convention on the Rights of the Child. Retried from http://www.refworld.org/docid/4538834f0.html (20 September 2016).

53. General Comment 14. CRC Committee on the right of the child to have his or her best interests taken as a primary consideration. Retrieved from http://www2.ohchr.org/English/bodies/crc/docs/GC/CRC_C_GC_14 ENG.pdf (20 August 2015).

54. General Comment No. 15 (2013). CRC Committee on the right of the child to the enjoyment of the highest attainable standard of health (art. 24). Retrieved from http://www.refworld.org/docid/51ef9e134.html (23 November 2017).

55. General Comment No. 2 on Article 14.1 (a), (b), (c) and (f) and Article 14. 2 (a) and (c) of the Women Protocol. Retrieved from http://www.achpr.org/files/instruments/general-comments-rightswomen/achpr_instr_general_comment2_rights_of_women_in_africa_ eng.pdf (5 June 2016).

56. General Comment 20 ICESCR Committee: Non-discrimination in economic, social and cultural rights. Retrieved from http://www.refworld.org/docid/4a60961f2.html ( 23 November 2017).

57. General comment on article 14(1)(d) and (e) of the Women Protocol retrieved http://www1.chr.up.ac.za/images/files/news/news_2013/English\%20 General\%20comments\%20booklet.PDF (3) May 2015).http://www.achpr.org/instruments/general-comments-rightswomen/ (12 June 2016).

58. General Recommendation 24 of the CEDAW Committee. Retrieved from http://www.refworld.org/docid/453882a73.html ( 13 September 2017).

59. Georgina Ahamefule v Imperial Medical Center \& Alex Molokwu, (2005) 5 NWLR (Pt.917) 51.

60. Gillick v. West Norfolk and Wisbech Area Health Authority and Another, (1986) 1 AC 112.

61. Glasier, (2006). Sexual and reproductive health: A matter of life and death. Lancet Vol. 368, 1597 \& 1599.

62. Heard, (1997). Human rights: Chimeras in sheep's clothing?. Retrieved from http://www.sfu.ca/ aheard/intro.html (30 March 2016). 
63. Human Rights Law Resource Centre. (2006). Human rights law resource manual 6. Retrieved atwww.hrlc.org.au/files/revised-ch-3implementation-of-human-rights.doc (2 June 2016).

64. ICESCR Committee Concluding Observations on Russia E/C.12/RUS/CO/5.

65. Idonije, Oluba \& Otamere, (2011). A study on knowledge, attitude and practice of contraception among secondary school students in Ekpoma, Nigeria. Journal of Pharmacy and Clinical Sciences (JPCS) Vol.2, 2227.

66. International Service for Human Rights. (2010). Simple guide to the UN treaty bodies. Retrieved from http://www.ishr.ch/sites/default/files/article/files/ISHR\%20Simple\%2 0Guide\%20to\%20the\%20UN\%20Treaty\%20Bodies.pdf (5 June 2016).

67. Ipas Africa Alliance (2016). Securing women's reproductive rights in Kenya: Endline Evaluation Report. Retrieved from https://www.government.nl/documents/reports/2016/10/18/securingwomen-s-reproductive-rights-in-kenya (15 February 2018).

68. Jaichand, (2010). An introduction to economic, social and cultural rights: Overcoming the constraints of categorization through implementation. In Chowdhury \& JBhuiyan (eds)., An introduction to I international human rights law. (Boston).

69. Kenya National Commission on Human Rights (2012). Realising Sexual and Reproductive Health Rights in Kenya: A Myth or a Reality?.

Retrieved

from http://www.knchr.org/portals/0/reports/reproductive_health_report.pd f (15 February 2018).

70. Kinaro, (2011). Perceptions as a barrier to contraceptive use among adolescents: A case study of Nairobi, 11-13. Retrieved from http://uaps2011.princeton.edu/papers/110662 (25 June 2013).

71. Kossen, (2012). Rights, respect, responsibility: Advancing the sexual and reproductive health and rights of young people through international human rights law. University of Pennsylvania Journal of Law and Social Change Vol. 15, 143-178.

72. Lansdown \& Wernham, (2012). Are protection and autonomy opposing concepts?' in IPPF (ed) Understanding young people's right to decide. Retrieved from http://www.ippf.org/sites/default/files/ippf_right_to_decide_03.pdf (12 June 2016).

73. Mbizvo \& Zaidi, (2010). Addressing critical gaps in achieving universal access to sexual and reproductive health (SRH): The case for improving adolescent SRH, preventing unsafe abortion, and enhancing 
linkages between SRH and HIV interventions. International Journal of Gynecology and Obstetrics Vol. 110, S3.

74. McLean, (2009). Constitutional deference, courts and socio- economic rights in South Africa. (Pretoria: Pretoria University Law Press).

75. Mermelstein \& Plax, (2016). Contraception for Adolescents. Current Treatment Options in Pediatrics. Vol. 2, 171-183

76. Mmari, (2010). STI treatment seeking behaviors among youth in Nigeria: Are there gender differences?. International Perspectives on Sexual and Reproductive Health Vol. 36, 72.

77. Ngige v. Obi (2006) 14 NWLR (Pt 991).

78. Nigerian Constitution, 1999 Cap 24 LFN 2004. Retrieved from http://www.nigeria-

law.org/ConstitutionOfTheFederalRepublicOfNigeria.html (5 March 2016).

79. National Health Policy 2004 http://cheld.org/wpcontent/uploads/2012/04/Nigeria-Revised-National-Health-Policy2004.pdf (23 November 2017).

80. National Reproductive Health Policy 2001 http://www.youthpolicy.com/Policies/Nigeria\%20National\%20Reproductive\%20Healt h\%20Policy\%20and\%20Strategy.pdf ( 23 November 2017).

81. Nwankwo v Yar Adua, (2013) 13 NWLR (Pt 1263) 81 CA.

82. Okeke \& Okeke, (2013). The justiciability of the non-justiciable constitutional policy of governance in Nigeria. IOSR Journal of Humanities and Social Science Vol. 7, 9. Retrieved from http://www.iosrjournals.org/iosr-jhss/papers/Vol7issue6/B0760914.pdf (7 March 2013).

83. Omo-Aghoja, Omo-Aghoja, Aghoja, Okonofua, Aghedo, Umueri, ....Inikori, (2009). Factors associated with the knowledge, practice and perceptions of contraception in rural Southern Nigeria. Ghana Medical Journal Vol. 43, 116.

84. Oronje (2013). The Kenyan national response to internationally agreed sexual and reproductive health and rights goals: a case study of three policies. Reproductive Health Matters. Vol. 21, 151- 160.

85. Paschim Banga Khet Mazdoor Samity \& Ors v State of West Bengal \& Anor (1996) AIR SC 2426, (1996) 4 SCC 37.

86. Resolution 65/234 of the UN General Assembly. Retrieved from http://www.un.org/en/development/desa/population/publications/pdf/ policy/Compendium/Volume\%20I/t_Annex\%20II.pdf (29 March 2016).

87. Riedel, (2009). The human right to health: conceptual foundations. In Clapham \& Robinson (eds)., Realizing the right to health. 
88. Savage-Oyekunle \& Nienaber (2017) Adolescents' access to emergency contraception in Africa: An empty promise?. African Human Rights Law Journal Vol. 17, 475.

89. Savage-Oyekunle \& Nienaber, (2015). 'Adolescent girls' access to contraceptive information and services in South Africa: What is going wrong?' (2). Journal of Contemporary Roman-Dutch Law Vol. 78, 548-553.

90. Savage-Oyekunle, (2015). Female adolescents and the right to access contraceptive information and services: Facing reality in Nigeria. Ife Juris Review Vol. 2, 623-636.

91. Shaw, (2009). Access to sexual and reproductive health for young people: Bridging the disconnect between rights and reality. International Journal of Gynecology and Obstetrics Vol. 106,132.

92. Singh \& Darroch, (2012). Adding It Up: Costs and Benefits of Contraceptive Services Estimates for 2012. pg. 4 \& 5. Retrieved from http://www.guttmacher.org/pubs/AIU-2012-estimates.pdf (4 June 2016).

93. Ssenyonjo, (2009). Economic, social and cultural rights in international law. (Oregon: Oxford and Portland).

94. Tayo, Akinola, Babatunde, Adewunmi, Dele Osinusi \& Shittu, (2011). Contraceptive knowledge and usage amongst female secondary school students in Lagos, Southwest Nigeria. Journal of Public Health and Epidemiology Vol. 3, pg. 34.

95. Twinomugisha, (2015). Fundamentals of health law in Uganda pg. 22. Retrieved from http://www.pulp.up.ac.za/pdf/2015_08/2015_08.pdf (15 April 2016).

96. Ujah, Aisien, Mutihir, Vanderjagt, Glew \& Uguru, (2005). Factors Contributing to Maternal Mortality in North-Central Nigeria: A Seventeen-year Review. African Journal of Reproductive Health Vol. 9, 28-40.

97. UNFPA. (2011). Country indicators - Nigeria in The state of the world's midwifery. Retrieved from http://www.unfpa.org/sowmy/resources/docs/country_info/profile/en _Nigeria_SoWMy_Profile.pdf (5 June 2016).

98. UNFPA. (2010). A human rights-based approach to programming: Practical implementation manual and training materials, pgs. 47-48. Retrieved from http://www.unfpa.org/sites/default/files/jahiapublications/documents/publications/2010/hrba/hrba_manual_in\%20f ull.pdf (2 June 2015).

99. UNFPA. (2013). Motherhood in childhood: Facing the challenge of adolescent pregnancy, pgs 2, 4-5 \& 13. Retrieved from 
http://www.unfpa.org/webdav/site/global/shared/swp2013/EN-

SWOP2013-final.pdf (17 March 2016).

100. UNFPA. (2016). Universal access to reproductive health:

Progress and challenges, 5. Retrieved from http://www.unfpa.org/sites/default/files/pub-

pdf/UNFPA_Reproductive_Paper_20160120_online.pdf (31 March 2016);

101. UNICEF. (2011). Demographic trends for adolescents: Ten key facts. Retrieved from http://www.unicef.org/sowc2011/pdfs/Demographic-Trends.pdf $\quad$ (8 May 2016).

102. UNICEF. (2013). At a glance: Nigeria statistics. Retrieved from

http://www.unicef.org/infobycountry/nigeria_statistics.html\#91(6 March 2016).

103. UNITED NATIONS. (2003). Youth and Health Issues - World YOUTH Report. pg. 108. Retrieved from http://www.un.org/esa/socdev/unyin/documents/ch04.pdf December 2017);

104. Verma, (2005). Justiciability of economic, social and cultural rights: Relevant case law. Retrieved from http://www.ichrp.org/files/papers/96/108_Justiciability_of_Economi c_Social_and_Cultural_Rights_Relevant_Case_Law_Verma_Shiv ani_2005_background.pdf_(24 October 2014).

105. WHO, UNICEF, UNFPA, World Bank Group, and United Nations Population Division (2015). Maternal mortality in 1990-2015: NIGERIA. Retrieved from http://www.who.int/gho/maternal_health/countries/nga.pdf February 2018).

106. WHO, (2006). Technical Report Series Preventing HIV/AIDS in young people: A systematic review of the evidence from developing $\begin{array}{lllll}\text { countries. } & \text { pg. } & 2 . & \text { Retrieved }\end{array}$ https://www.researchgate.net/profile/David_Ross2/publication/68660 76_Preventing_HIVAIDS_in_young_people_A_systematic_review_ of_the_evidence_from_developing_countries_Introduction_and_ratio nale/links/02e7e53a19944b7f6c000000/Preventing-HIV-AIDS-inyoung-people-A-systematic-review-of-the-evidence-fromdeveloping-countries-Introduction-and-rationale.pdf (28 December 2017).

107. WHO. (2010). Measuring sexual health: Conceptual and practical considerations and related indicators $2 \& 10$. Retrieved from 
http://whqlibdoc.who.int/hq/2010/who_rhr_10.12_eng.pdf

September 2014).

108. WHO. Gender and human rights: Defining sexual health.

Retrieved from

http://www.who.int/reproductivehealth/topics/gender_rights/defining _sexual_health/en/ (20 September 2015).

109. WHO. (2018). SDG 3: Ensure healthy lives and promote wellbeing for all at all ages Retrieved from http://www.who.int/sdg/targets/en/ ( 27 December 2017).

110. WHO. The right to health: Fact sheet (No. 31) 27. Available http://www.ohchr.org/Documents/Publications/Factsheet31.pdf. (24 April 2016).

111. Cook, Dickens \& Fathalla, (2003). Reproductive health and human rights, integrating medicine, ethics and law.

112. Women Protocol. Resolution AHG/RES.240 (XXXI).

113. World Bank (2017). Adolescent fertility rate. Retrieved from https://data.worldbank.org/indicator/SP.ADO.TFRT (18 February 2018)

114. Zimbabwe Human Rights NGO Forum v Zimbabwe, (2006) AHRLR 128 (ACHPR 2006). 